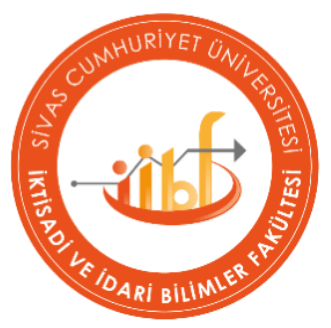

\title{
IS PER CAPITA REAL GDP STATIONARY IN G-7 COUNTRIES? NEW EVIDENCE FROM A FOURIER PANEL UNIT ROOT TEST
}

\section{Tunahan HACIIMAMOĞLU ${ }^{1}$}

\section{Abstract}

The stability of macroeconomic variables and whether the impact of a shock on these variables is permanent or temporary are important for policy-makers and researchers. As an indicator of growth and prosperity, gross domestic product (GDP) is among the important macroeconomic variables. After all, due to the advantages of current panel data analysis techniques over conventional methods, it is important to use the aforementioned methods in analyzing the existence of unit-root for GDP. Accordingly, the aim of this study is to investigate whether per capita real GDP in G-7 countries followed a stationary process between 1970-2019 with a stronger unit-root test (BCIPS) that takes into consideration cross-section dependence, multi-factor structure, and structural changes. Empirical results revealed that per capita real GDP for G-7 countries has a stationary structure. In this context, it has been determined that the impact of a shock on per capita real GDP is temporary in G-7 countries, therefore, by means of monetary or fiscal policy instruments, it is not necessary to intervene in the fluctuations occurring at the output level.
Article History:

Date submitted:

5 June 2021

Date accepted:

23 August 2021

\section{Jel Codes:}

C23, E32, F43

\section{Keywords:}

BCIPS Unit-root Test, Stationarity, G-7 Countries, Per Capita Real GDP

Suggested Citation: Haciimamoğlu, T. (2021). Is Per Capita Real GDP Stationary in G-7 Countries? New Evidence from a Fourier Panel Unit Root Test. Cumhuriyet University Journal of Economics and Administrative Sciences, 22(2), 123-144.

${ }^{1}$ Res. Asst. Dr., Recep Tayyip Erdogan University, Faculty of Economics and Administrative Sciences, Department of Economics, tunahan.haciimamoglu@erdogan.edu.tr, ORCID ID: 0000-0003-1474-8506. 


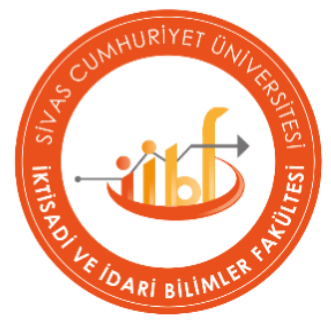

\section{G-7 ÜLKELERINNDE KISŞI BAŞI REEL GSYIH DURAĞAN MIDIR? FOURIER PANEL BIRIMM KÖK TESTINDEN YENİ KANITLAR}

\section{Tunahan HACIIMAMOĞLU ${ }^{1}$}

$\ddot{O} z$

Makroekonomik değişkenlerin istikrarı ve bu değişkenler üzerinde görülen bir şokun etkisinin kalıcı mı yoksa geçici mi olduğu politika yapıcılar ve araştırmacılar için önemlidir. Büyüme ve refahın bir göstergesi olarak gayri safi yurt içi hasıla (GSYIH) ise önemli makroekonomik değişkenler arasında yer almaktadır. Bununla birlikte güncel panel veri analizi tekniklerinin geleneksel yöntemlere göre sahip olduğu avantajlar nedeni ile GSYIH için birim kökün varlığının analiz edilmesinde bahsi geçen yöntemlerin kullanılması önem arz etmektedir. Bu doğrultuda bu çalışmanın amacı yatay kesit bağımlılığını, çok faktörlü yapıyı ve yapısal değişimleri dikkate alan daha güçlü yeni bir birim kök testi (BCIPS) ile 1970-2019 dönemi için G-7 ülkelerinde kişi başı reel GSYIH verisinin durağan bir süreç izleyip izlemediğini araştırmaktır. Analiz sonuçları G-7 ülkeleri için kişi başı reel GSYIH verisinin durağan bir yapıya sahip olduğunu ortaya koymaktadır. Elde edilen sonuç bağlamında G-7 ülkelerinde ortaya çıkan bir şokun etkisinin geçici olduğu dolayısıyla çıktıda ortaya çıkan herhangi bir dalgalanma sürecine para veya maliye politikası araçları ile müdahale edilmesine gerek görülmediği tespit edilmiştir
Makale Geçmişi:

Iletilen Tarih:

5 Haziran 2021

Kabul Tarihi:

23 Ağustos 2021

Jel Kodlart:

C23, E32, F43

Anahtar Kelimeler: BCIPS Birim-Kök

Testi, Durağanlık, G-7

Ülkeleri, Kişi Başı

Reel GSYIH.

Önerilen Alıntı: Haciimamoğlu, T. (2021). G-7 Ülkelerinde Kişi Başı Reel GSYIH Durağan Mıdır? Fourier Panel Birim Kök Testinden Yeni Kantlar. Cumhuriyet Üniversitesi İktisadi ve İdari Bilimler Dergisi, 22(2), 123-144.

${ }^{1}$ Arş. Gör. Dr., Recep Tayyip Erdoğan Üniversitesi, İktisadi ve İdari Bilimler Fakültesi, İktisat Bölümü, tunahan.haciimamoglu@erdogan.edu.tr, ORCID ID: 0000-0003-1474-8506. 
Tunahan HACIIMAMOĞLU, 2021 Cilt: 22, Sayl: 2, ss. 123-144.

\section{INTRODUCTION}

Macroeconometric models intend to test the processes of key macroeconomic indicators by using time series or cross-sectional data analysis within the framework of a macroeconomic model (Pagan and Wickens, 1989; Wallis, 1989). Considering that the parameters of macroeconomic variables are evident, it is important to test the relevant variables by setting a policy simulation before policy implementation. Along with policy makers' control over policy instruments such as government spending, interest rate and tax rate, they want to know how actual output, employment, trade balances change in the economy and their economic effects when they use these instruments (Kira, 2013: 150). Thus, it is thought that examining the processes of macroeconomic variables with more modern methods and models is determinative in the realization of more effective policy implementations.

It is argued that modeling real output levels as a trend stationary or difference stationary process has important implications for macroeconomic policy, modeling, and forecasting (Nelson and Plosser, 1982). A unit root process stating that the effect of shocks is permanent in real output contradicts the view that business cycles are stable fluctuations around a deterministic trend (Narayan, 2007: 374-375). Hence, examining the unit root or stability processes of macroeconomic variables plays an important role for researchers and policy makers (Tiwari et al., 2012: 3-4).

Economic growth, which is used as an indicator of development and welfare, is one of the most important macroeconomic indicators in an economy. The variable of per capita real GDP is mostly used as an indicator of economic growth. However, forecasting of the economic growth trend and the determination of the effectiveness of economic policies are generally based on the variable of per capita real GDP.

The process of investigating the stability of macroeconomic variables, especially the real GDP variable, began with Nelson and Plosser (1982). Interest in this subject has increased with the works of Stulz and Wasserfallen (1985), Stocks and Watson (1986), Campbell and Mankiw (1987), Phillips and Perron (1987), Evans (1989), Rudebusch (1993), Ben-David and Papell (1995), Cheung and Chinn (1996), Murray and Nelson (2000), Rapach (2002), Smyth and Inder (2004), Narayan (2007), Chen (2008).

Early studies have mostly provided evidence that real GDP data contains unit-root. However, it is claimed that this result is owing to the impotence of the conventional unit-root analysis methods (Chang et al., 2005: 1). It is stated that macroeconomic variables have a nonlinear character, especially in recent years. Thus, the results obtained with a linear unit-root analysis such as ADF are deviated. In order to overcome this problem, it is emphasized that nonlinear test methods should be considered (Lee, 2014: 508). Although the results pertaning to the existence of unit-root in macroeconomic variables were mostly obtained in the early studies, evidence of stationary has begun to be determined in the analysis performed with panel unit- root tests developed by Levin, Lin and Chu (2002), Lm, Pesaran and Shin (2003), Maddala and Wu (1999), Pesaran (2007), which consist of time dimension and cross-section dimension. 


\section{IS PER CAPITA REAL GDP STATIONARY IN G-7 COUNTRIES? NEW EVIDENCE FROM A FOURIER PANEL UNIT ROOT TEST}

Unit-root tests have made significant progress, especially in the last 20 years. Firstgeneration unit-root tests, introduced into the literature by Banerjee (1999), Levin, Lin and Chu (2002), Lm, Pesaran and Shin (2003), Maddala and Wu (1999), are based on the assumption of cross-section independence. On the other hand, the bias results caused by ignoring the crosssection dependence in panel data analysis have clearly revealed the lack of test methods that take into account the dependence between sections. This shortcoming in panel data analysis has been eliminated by unit-root tests put forward by Chang $(2002,2004)$, Bai and $\mathrm{Ng}(2004,2010)$, Moon and Peron (2004), Smith et al. (2004), Cerrato and Sarantis (2007), Pesaran (2007), Pesaran et al. (2013). However, all of these tests examine the presence of the unit-root under the assumption that there are no structural breaks. Even though the Carrion-i-Silvestre (2005) and Im, Lee, and Tieslau (2005) panel unit-root tests allow structural changes (sudden breaks), it is necessary to have prior knowledge about the break dates, the number of breaks and the form of a break for these two tests.

The dummy variable method is used to capture structural breaks in the analyses. Becker, Enders, and Lee (2006), Enders and Lee (2012), Rodrigues and Taylor (2012), using the flexible Fourier form approach, however, state that it is more advantageous to use the Fourier form method instead of using the dummy variable with flexible Fourier form approach. Since the Fourier form captures the structural breaks more strongly, the test eliminates the concerns about the form of the break, when and how many breaks frequently occurred in unit-root analysis (Omay, 2015). Pesaran, Smith, and Yamagata (2013) extended the cross-sectional augmented Dickey-Fuller (CADF) panel unit-root test to multi-factor error structure and developed a new unit-root test based on the simple average of the cross-sectional augmented Sargan and Bhagava (1983) test statistics. Lee, Wu, and Yang (2016) broaden Pesaran, Smith and Yamagata's (2013) multi-factor error structure model with the Fourier function and proposed a new unit-root test (BCIPS) that captures smooth structural changes in deterministic terms.

The aim of this study is to scrutinize the stationarity of per capita real GDP for the 19702019 period in G-7 countries. To that end, Lee, Wu and Yang (2016) BCIPS (the breaks and cross-section dependence augmented by Im, Pesaran and Shin) panel unit-root test was employed in the study. The unique aspects of the study and its contributions to the literature are as follows: First of all, it is important to determine whether the impact of shocks on macroeconomic indicators is permanent or not, in terms of determining appropriate policies and their effectiveness. Therefore, as an important macroeconomic indicator, determining whether fluctuations in GDP stabilize in the long term is decisive for the policies to be implemented by all countries regardless of developed and developing countries. The second is the use of an up-todate second-generation unit-root test in unit-root analysis of per capita real GDP data in G-7 countries. First-generation unit-root tests ignore cross-section dependence and second-generation unit-root tests disregard structural changes mostly. BCIPS unit-root test is more advantageous than first and second-generation unit-root tests in terms of considering cross-section dependence and unobservable common factors and allowing a smooth break in structural changes. Because of its advantages, it can be stated that the results of the unit-root analysis obtained for the G-7 countries are stronger. Therefore, more consistent and effective policy recommendations can be made. 
Tunahan HACIIMAMOĞLU, 2021 Cilt: 22, Sayı: 2, ss. 123-144.

The rest of the study is organized as follows. The second chapter of the study includes a literature review. The third chapter consists of the data set and the scope. The fourth chapter, in which the econometric method is explained, is followed by the fifth part where the empirical results are reported. Finally, the study is completed with the results and recommendations.

\section{LITERATURE REVIEW}

With their study titled "Trend and Random Walk in Macroeconomic Time Series", Nelson and Plosser (1982), attracted attention to the investigation of the potential stability of macroeconomic variables and became the pioneer of the relevant literature. Nelson and Plosser (1982) stated that modeling the output level by taking into consideration the trend stationarity or a different stationarity process has important implications for macroeconomic policies. By this means, the stationarity of macroeconomic variables has taken its place among the issues highlighted by policy-makers and researchers. With the help of different methods, the stationarity of other macroeconomic variables (exchange rate, unemployment, inflation, energy consumption, etc.), especially per capita real GDP, has been analyzed and it has been tried to determine whether the effects of shocks were temporary or permanent. On the other hand, it has been observed that the study results on the stationarity of macroeconomic variables differ according to the group of countries, the period covered and the methods of econometric analysis. In this regard, the literature chapter of the study focuses on studies that investigate the stationarity of the per capita real GDP.

Strauss (2000) investigated the stationarity of per capita real GDP for 48 states of the U.S.A between 1929 and 1995. Unit-root analysis methods proposed by Dickey and Fuller (1979), Aboaf and Jorion (1990), Levin and Lin (1993), Im, Pesaran and Shin (1996) were used. In contrast to the ADF unit-root empirical results, it was determined that the per capita real GDP for 48 states was stationarity.

Smyth (2003) examined the stationarity of per capita real GDP data for the period 19521998 in 24 provinces of China using the unit-root analysis proposed by Im, Pesaran and Shin (1996). In the study, the empirical tests were applied for the sub-panels (whole panel, eastern provinces, western provinces, central provinces) over the data sets adapted the original and cross section dependency. In the empirical results, it was determined that the adapted per capita real GDP data was stationary for the provinces of China.

Narayan (2007) scrutinized the stationarity of per capita real GDP of G-7 countries in the period between 1870 and 2001. In the study using the break unit-root test developed by Lee and Strazicich (2003), it was found that the per capita real GDP of all countries had a stationary structure except for Italy and Germany.

Öztürk and Kalyoncu (2007) investigated the stationarity of per capita real GDP of 27 OECD countries during the period from 1950 to 2004. In the study, the unit-root test method put forward by Im, Pesaran and Shin (1997) was used and it was concluded that the per capita real GDP was not stationary in the majority of OECD countries. 


\section{IS PER CAPITA REAL GDP STATIONARY IN G-7 COUNTRIES? NEW EVIDENCE FROM A FOURIER PANEL UNIT ROOT TEST}

In order to analyze the stationarity of per capita real GDP of China's 25 provinces for the period 1952-1998, Zhang et al. (2007) used SURADF panel unit-root test developed by Breuer et al. (2001). Empirical results revealed that the per capita real GDP was stationary in the 4 provinces of China, and the 21 provinces of China have unit-root.

Chen (2008) analyzed the per capita real GDP of 19 developed countries for the period 1870-2003 with unit-root test allowing two breaks proposed by Lee and Strazicich (2003). The one break unit-root test results showed that the per capita real GDP was stationary for Australia, France, Germany, Japan, England, and the USA. In the two breaks unit-root analysis, evidence of stationary was obtained for 11 countries.

Murthy and Anoruo (2009) researched the stationarity of per capita real GDP for 27 African countries between 1960 and 2007, using the panel unit-root method developed by Kapetanios, Shin, and Snell (2003). The results of the analysis demonstrated that only a third of 27 African countries had a stable process in their per capita real GDP.

Çinar (2010) inquired the stationary process of per capita real GDP data of 27 OECD countries for the period 1960-2008 in each OECD country. In the study, second generation panel unit-root tests, allowing for cross-section results and regarding the cross-section dependence, were used together with first-generation unit-root tests. First and second-generation unit-root analyzes provided results supporting a non-stationary process for all OECD countries.

Güloğlu and İvrendi (2010) scrutinized the stationary characteristics of per capita real GDP data for 1965-2004 in 19 Latin American countries. In the study, SURADF test proposed by Breuer et al. (2001) and CADF unit-root test methods developed by Pesaran (2006), which regards cross-section dependence, were used. From the results of the analysis, it was determined that the per capita real GDP in Latin American countries had unit-roots except for Belize, Bolivia, Panama, and Uruguay.

$\mathrm{Su}$ and Cheng (2011) investigated the stationarity of per capita real GDP of 9 countries from Central and Eastern Europe with the Fourier stationarity unit-root test introduced by Enders and Lee $(2004,2009)$ as well as conventional unit-root tests. Conventional unit-root test results showed that the per capita real GDP included unit-root for these 9 countries. On the other side, from the results of Fourier unit-root analysis, it has been determined that the per capita real GDP for Bulgaria, Lithuania and Romania had a stationary process.

Tiwari et al. (2012) analyzed the stationarity of per capita real GDP of 17 Asian countries between 1950 and 2009 using first and second generation test methods. Empirical tests were also applied to sub-panels such as South Asia, East Asia, and high-income Asian countries. The second-generation test results demonstrated that the per capita real GDP was stationary in the sub-panels such as East Asia and high-income Asian countries.

Tülümce and Zeren (2013) investigated the stationarity of per capita real GDP data during the period from 1970 to 2011 for 15 European Union member countries. In the study, analyzes

were performed using unit-root tests suggested by Im, Pesaran and Shin (2003) and Uçar and Omay (2009). Empirical results revealed that the per capita real GDP for 15 member countries of the European Union followed a non-linear stable process. 
Aslanidis and Fountas (2014) tested the stationarity of real GDP for the period 1870-2008 of 19 industrial countries with the cross-sectional augmented IPS (CIPS) panel unit-root test developed by Pesaran (2007). In the study, the analyzes were performed by categorizing into 5 periods and 4 country groups. From the results of the analysis, it was found that real GDP was relatively less stationary in country groups during periods of the Bretton Woods system and the Gold standard system.

Chang et al. (2014) researched whether the impact of shocks on GDP in 52 African countries for the period 1969-2011 is temporary or not. Conventional unit-root test results showed that the per capita real GDP variable had a unit-root. However, second-generation unitroot tests revealed that the per capita real GDP variable was stationary in 50 of 52 African countries. It has been pointed out that the results of the study are consistent with the Neoclassical approach and it is stated that the effect of shocks on output in African countries was temporary. As a result, there is no need for policy implementations of Keynesian economics in African countries.

Lee (2014) analyzed the stationarity of per capita real GDP for the 31 regions of China between 1979 and 2009. In the study, Panel Kwiatkowski-Phillips-Schmidt-Shin (PANKPSS) unit-root analysis method was used, it was concluded that the per capita real GDP was nonstationary for all regions.

Azimi (2015) investigated whether Afghanistan's per capita real GDP followed a stationary process for the 2001-2014 period. Conventional unit-root tests developed by Dickey and Fuller (1979) and Phillip and Perron (1988) were used in the study. From empirical results, it was determined that the per capita real GDP of Afghanistan had a unit-root.

Cushman (2016) examined the stationarity of real GDP of USA in the post-World War II period. The results of many unit-root analyses applied to the USA between 1947 and 2007 indicated that the impact of shocks on real GDP was permanent.

Furat (2016) analyzed the stationarity of the real GDP of 35 developed countries between 1960 and 2011 with the aid of first and second-generation unit-root tests. Developed by Dickey and Fuller (1979) and Phillips and Perron (1988), Kwiatkowski, Phillips, Schmidt and Shin (1992), Rothenberg and stock (1996), Im, Pesaran and Shin (2003) and Pesaran (2006), panel unit-root tests were used in the analysis. In the empirical results obtained from all these tests, it was determined that real GDP for 35 countries included unit-root.

Omay et al. (2017) tested the stationary process of the USA's real GNP data between 1875 and 2015. In the study, Dickey-Fuller type unit-root test method in the Fractional Frequency Flexible Fourier Form (FFFFF-DF) developed by Omay (2015) was used. The results achieved from this test provided evidence that real GNP was stationary in the United States.

Zeren and Işlek (2019) researched the stationarity of per capita real GDP in D8 countries between 1960 and 2014 in their study. Accordingly, an up-to-date panel unit-root test (BCIPS) method, taking into account cross-section dependence, Fourier functions and multi-factor structure, developed by Lee, Wu and Yang (2016), was used. In the study, the stationary analysis of per capita real GDP variable was implemented by considering common factors such as labor 


\section{IS PER CAPITA REAL GDP STATIONARY IN G-7 COUNTRIES? NEW EVIDENCE FROM A FOURIER PANEL UNIT ROOT TEST}

force, capital stock and human capital, whose impacts on economic growth cannot be ignored. From the empirical results, regarding the common factors, it is revealed that the per capita real GDP was stationary in D-8 countries.

Konat and Kizlkaya (2020) tested the stationarity of per capita real GDP of 28 OECD countries for the period of 1970-2019. In this context, the CADF and CIPS panel unit-root tests of Pesaran (2006), which do not take into account the structural breaks, and Li et al. (2015) panel unit-root test, which regards sharp and smooth breaks were used. According to the panel unit-root analysis, it was concluded that the per capita real GDP was stationary for Australia, Austria, France, Mexico, New Zealand, South Korea and Sweden.

As it can be seen in the literature, traditional methods were mainly used in the first period studies in which the stagnation of the per capita real GDP variable was investigated. In the following studies, the sufficiency of traditional tests was emphasized and the importance of performing stationarity analyzes using more modern test techniques was mentioned more frequently. In this direction, it has been examined whether per capita real GDP is stationary or not by employing new test techniques that take into account the cross-sectional dependence and structural break. In recent studies, it has been seen that more powerful and modern test techniques, which allow for soft breaks with the Fourier feature, have begun to be used in stationarity analysis. This study intends to contribute to this field by analyzing the stationarity properties of the per capita real GDP variable with a multifunctional and more powerful unit root test, which takes into account the cross-sectional dependence and multi-factor structure and allows for a soft break with the Fourier feature.

\section{DATA SET}

The stationarity of macroeconomic variables is important with respect to the impact of shocks and the effectiveness of policies implemented. In this sense, the present study aims to test the stationarity of per capita real GDP in the G-7 country (Germany, the United States of America (USA), France, England, Italy, Japan, and Canada) between 1970-2019. The G-7 is an international organization established in 1975 by the world's leading industrial countries to take an active role in world politics and to struggle against global and economic challenges. These countries, which are in the position of global power, also direct the world economy through the policies they implement. Solow (1956) notes the importance of labor force and capital stock inputs in determining the level of economic growth under the assumption of constant returns to scale, no externalities exist, and the condition of perfect competition in his study titled "A Contribution to Economic Growth Theories", which deals with the facts regarding the concept of economic growth. Within the framework of endogenous growth theories, Lucas (1988) and Romer (1989) emphasized that the increase in human capital, open economies, and economic integration would have a positive impact on economic growth. In the context of these theories, in this study, the per capita real GDP, the main variable of the study, has been tested with common factors such as labor (Emp), capital (Cap) and openness (Trade). Eickmeier (2009) states that the number of unobserved common factors, ranging between two and six, is sufficient in the analysis 
of macroeconomic variables. Lee et al. (2016), Zeren and İşlek (2019) determined the number of factors $\left(\mathrm{m}_{\max }\right)$ as 4 in their studies. In this context, stationary analyzes have been performed over $\mathrm{m}_{\max }=4$ in this study. Data on GDP and Trade variables have been obtained from the World Bank's (WB) "World Development Indicators (WDI)" database. Data on Emp and Cap variables have been obtained from the "Penn World Table-10 (PWT)" source revealed by Feenstra, Inklaar and Timmer (2015). Gauss 20 program has been used for the empirical results in this study. The description, explanation, unit, and source information about the variables used in the study are included in Table 1. Since the variables are in different units and scales, the log-transformations of the datasets have been calculated. Subsequently, the log-transformed datasets have been used in the empirical analysis.

Table 1: Description of Variables

\begin{tabular}{|c|c|c|c|c|}
\hline Variable & Definition & Explanation & Unit & Reference \\
\hline GDP & $\begin{array}{l}\text { Per capita } \\
\text { real GDP }\end{array}$ & The real gross domestic product per capita value & $\begin{array}{l}\text { US } \\
\text { Dollar }\end{array}$ & WB-WDI \\
\hline Emp & $\begin{array}{l}\text { Total Labor } \\
\text { Force }\end{array}$ & The number of people working in the labor market & $\begin{array}{l}\text { Number } \\
\text { of People }\end{array}$ & PWT-10 \\
\hline Cap & Capital Stock & The physical capital stock & $\begin{array}{l}\text { US } \\
\text { Dollar }\end{array}$ & PWT-10 \\
\hline Trade & $\begin{array}{c}\text { Trade } \\
\text { Openness }\end{array}$ & $\begin{array}{l}\text { The share of the volume of goods and services } \\
\text { foreign trade in GDP }\end{array}$ & $\%$, GDP & WB-WDI \\
\hline
\end{tabular}

\section{METHODOLOGY}

Before proceeding to panel unit-root analysis, it is essential to check the cross-section dependence in the countries that are the subject of the analysis. Conventional unit-root tests are based on the assumption that sections are independent. Therefore, it is maintained that the empirical results would be biased and inconsistent when cross-section dependence is ignored (Menyah vd., 2014: 389; Phillips ve Sul, 2003). Within this scope, in the first stage of the study, it is determined whether there is a cross-section dependence or not, and then the panel unit-root analysis method is used in accordance with this situation.

\subsection{Cross-Section Dependence Tests}

Cross-section dependence is seen as a major problem in panel data analysis. In the case of cross-section independence, first-generation tests are used, however, in the presence of crosssectional dependence (CSD), second-generation tests must be employed. Breusch and Pagan (1980) LM test, Pesaran (2004) $\mathrm{CD}_{\operatorname{lm}}$ test, Pesaran (2004) CD test, and Pesaran et al. (2008) $\mathrm{LM}_{\mathrm{adj}}$ tests are frequently employed in the literature to detect cross-section dependence. The efficiency (power) of cross-section dependence tests differs depending on the time (T) and crosssection $(\mathrm{N})$ dimensions. 


\section{IS PER CAPITA REAL GDP STATIONARY IN G-7 COUNTRIES? NEW EVIDENCE FROM A FOURIER PANEL UNIT ROOT TEST}

Breusch and Pagan (1980) have introduced a cross-section dependence test based on the Langrange multiplier. It offers effective results in panels where $\mathrm{T}$ is relatively large and $\mathrm{N}$ is relatively small. The LM test statistic is shown in Equation (1):

$$
L M=T \sum_{i=1}^{N-1} \sum_{j=i+1}^{N} \widehat{p}_{i j}^{2}
$$

Developed by Breusch and Pagan (1980), the LM test loses its power in large panels with $\mathrm{T} \rightarrow \infty$ and $\mathrm{N} \rightarrow \infty$. At this point, Pesaran (2004) has developed a scaled version of the LM test for large panels. The $\mathrm{CD}_{\mathrm{lm}}$ test statistic is seen in Equation (2):

$$
C D_{l m}=\left(\frac{1}{N(N-1)}\right)^{\frac{1}{2}} \sum_{i=1}^{N-1} \sum_{j=i+1}^{N}\left(T \hat{p}_{i j}^{2}-1\right)
$$

Pesaran (2004) CDlm test experiences deterioration in panels where $\mathrm{N}$ is larger than $\mathrm{T}$. In order to address this deficiency, Pesaran (2004) has proposed an appropriate test statistic for $\mathrm{N}>\mathrm{T}$. This test statistic is included in Equation (3):

$$
C D=\sqrt{\left(\frac{2 T}{N(N-1)}\right)}\left(\sum_{i=1}^{N-1} \sum_{j=i+1}^{N} \hat{p}_{i j}\right)
$$

Pesaran (2004) CD test loses its power when the individual pair-wise correlation average differs from zero and the population's pair-wise correlation average is zero. In order to make up for this deficiency, Pesaran et al. (2008) have put forward a deviation-sensitive test statistic. The adjusted form of $\mathrm{LM}_{\mathrm{adj}}$ test statistic is presented in Equation (4):

$$
L M_{a d j}=\sqrt{\left(\frac{2}{N(N-1)}\right)} \sum_{i=1}^{N-1} \sum_{j=i+1}^{N} \widehat{p}_{i j} \frac{(T-k) \hat{p}_{i j}^{2}-\mu_{T_{i}}}{\sqrt{v_{T_{i}}^{2}}}
$$

The $k$ in Equation 4 indicates the number of independent variables. $\mu_{T_{\mathrm{II}}}$ and $v_{T_{\mathrm{I} J}}^{2}$ represent the mean and variance, respectively.

\subsection{Panel Unit-root Test}

Lee, $\mathrm{Wu}$, and Yang (2016) expanded the multi-factor error structure model of Pesaran Smith and Yamagata (2013) through the Fourier function. In this way, break augmented IPS (BCIPS) test has been developed with the structure that allows cross-section dependence, multifactor error, and smooth break in deterministic components. The BCIPS test performs well enough when $\mathrm{T}>100$. In addition, it is stated that this test shows good performance unless $\mathrm{T}<50$. Lee et al. (2016) have introduced a new ADF model by expanding the "cross-sectional augmented ADF" (CADF) statistics to "break and cross-sectional augmented ADF" (BCADF) statistics. The BCADF test statistics are as follows:

The OLS estimation of the single-factor ADF equation, taking into account the crosssection dependence and breaks, is shown in Equation (5):

$$
\Delta y_{i t}=c_{i, 0}+c_{i, 1} \sin \left(\frac{2 \pi k t}{T}\right)+c_{i, 2} \cos \left(\frac{2 \pi k t}{T}\right)+c_{i, 3} \bar{y}_{t-1}+c_{i, 4} \Delta \bar{y}_{t}+b_{i} y_{i, t-1}+e_{i, t}
$$


In the presence of a multi-factor error structure, regarding the breaks and cross-section dependence, the ADF equation is expressed in Equality (6):

$$
\begin{aligned}
& \Delta y_{i t}=c_{i, 0}+c_{i, 1} \sin \left(\frac{2 \pi k t}{T}\right)+c_{i, 2} \cos \left(\frac{2 \pi k t}{T}\right)+c_{i, 3}^{\prime} \bar{z}_{t-1}+c_{i, 4}^{\prime} \Delta \bar{z}_{t}+c_{i, 5}^{\prime} \Delta \bar{z}_{t-1}+ \\
& c_{i, 6} \Delta y_{i, t-1}+b_{i} y_{i, t-1}+e_{i, t}
\end{aligned}
$$

BCADF regression is demonstrated in equation (7). Where $\mathrm{p}$ and $\mathrm{k}$ represent the optimal lag length and frequency number, respectively:

$$
\begin{aligned}
& \Delta y_{i t}=c_{i, 0}+c_{i, 1} \sin \left(\frac{2 \pi k t}{T}\right)+c_{i, 2} \cos \left(\frac{2 \pi k t}{T}\right)+c_{i, 3}^{\prime} \bar{z}_{t-1}+c_{i, 4}^{\prime} \Delta \bar{z}_{t}+\sum_{j=1}^{p} c_{i, 5, j}^{\prime} \Delta \bar{z}_{t-j}+ \\
& \sum_{i=1}^{p} c_{i, j, j}^{\prime} \Delta \bar{z}_{t-j}+\sum_{i=1}^{p} c_{i, 6, j} \Delta y_{i, t-j}+b_{i} y_{i, t-1}+e_{i, t} t=1,2, \ldots, T
\end{aligned}
$$

Lee et al. (2016) proposed the "smooth break and cross-sectional augmented IPS" (BCIPS) statistic as a test statistic that takes into account structural breaks and cross-section dependence by calculating the average of BCADF statistics. The BCIPS statistic is shown in Equation (8):

$$
\operatorname{BCIPS}(\mathrm{N}, \mathrm{T})=\frac{1}{N} \sum_{i=1}^{N} t_{i}(N, T)
$$

\section{EMPIRICAL RESULTS}

In this study, the existence of cross-section dependence in G-7 countries has been examined by Breusch and Pagan (1980) LM, Pesaran (2004) CD $\mathrm{D}_{\mathrm{lm}}$, Pesaran (2004) CD and Pesaran et al. (2008) $\mathrm{LM}_{\text {adj }}$ tests. Table 2 shows the cross-section dependence test results for constant, and constant and trend models. Accordingly, the null hypothesis that "there is no crosssection dependence" for G-7 countries is rejected at the $1 \%$ significance level in both models. Thus, the presence of cross-section dependence has been determined in G-7 countries.

Table 2: Cross-Section Dependence Test Results

\begin{tabular}{|l|c|c|c|c|}
\hline \multirow{2}{*}{ CD Tests (GDP) } & \multicolumn{2}{|c|}{ Constant Model } & \multicolumn{2}{c|}{ Constant and Trend Model } \\
\cline { 2 - 5 } & Test Statistic & p-value & Test Statistic & p-value \\
\hline LM & $103.601 * * *$ & 0.000 & $107.950 * * *$ & 0.000 \\
\hline CD & $12.746 * * *$ & 0.000 & $13.417 * * *$ & 0.000 \\
\hline CD & $-4.688^{* * *}$ & 0.000 & $-4.764 * * *$ & 0.000 \\
\hline LM $_{\text {adj }}$ & $34.735 * * *$ & 0.000 & $34.016 * * *$ & 0.000 \\
\hline
\end{tabular}

Note: *** represents the $1 \%$ significance level. The maximum lag length is 3 . 


\section{IS PER CAPITA REAL GDP STATIONARY IN G-7 COUNTRIES? NEW EVIDENCE FROM A FOURIER PANEL UNIT ROOT TEST}

Pesaran et al. (2013) has broadened Pesaran (2007)'s CIPS panel unit-root test with multifactor error terms. This test method provides a CIPS test statistic that regards the unobservable common factor structure. Lee et al. (2016) have improved BCIPS test, integrating the Fourier function to the panel unit-root test of Pesaran et al. (2013). In the BCIPS test, which takes into account the structural changes with the Fourier function feature, the CIPS test results are also reached. It is also possible to attain CIPS test results from BCIPS test results. Table 3 and 4 show the BCIPS test results for the constant model and constant and trend model, respectively. CIPS and BCIPS results for two $(m=2)$, three $(m=3)$ and four-factor $(m=4)$ situations have been reported in Table 3 and 4, including one, two and three common factors respectively, together with the single-factor $(\mathrm{m}=1)$ situation in which no common factors are included.

Table 3: The BCIPS and CIPS Panel Unit-root Tests for Per Capita Real GDP

\begin{tabular}{|l|c|c|c|c|}
\hline Constant Model & $(p, k)$ & {$[N, T]$} & CIPS & BCIPS \\
\hline $\mathrm{m}=1$ & $(1,1)$ & {$[7,50]$} & -1.7178 & -2.6964 \\
\hline $\mathrm{m}=2$ & & & & \\
\hline Emp & $(1,2)$ & {$[7,50]$} & -2.0518 & -2.7531 \\
\hline Cap & $(1,1)$ & {$[7,50]$} & -1.9670 & $-3.4746^{* * *}$ \\
\hline Trade & $(1,1)$ & {$[7,50]$} & -1.6360 & -3.0607 \\
\hline $\mathrm{m}=3$ & & & & \\
\hline Emp, Cap & $(4,5)$ & {$[7,50]$} & -2.5765 & $-2.3606^{* *}$ \\
\hline Emp, Trade & $(1,1)$ & {$[7,50]$} & -2.5645 & $-3.5945^{* * *}$ \\
\hline Cap, Trade & $(1,1)$ & {$[7,50]$} & -1.9360 & $-3.3889^{* *}$ \\
\hline $\mathrm{m}=4$ & & & & \\
\hline Emp, Cap, Trade & $(2,1)$ & {$[7,50]$} & -2.2873 & $-4.2972^{* * *}$ \\
\hline
\end{tabular}

Note: $* * *$ and $* *$ represent $\% 1$ and $5 \%$ significance levels, respectively. $m$ indicates the number of factors in the model. The $p$ and $k$ are determined according to the Schwarz Bayesian Criterion (SBC) rule. Critical values are obtained from Pesaran (2007), Pesaran et al. (2013), Lee et al. (2016).

According to the CIPS test results in Table 3, the null hypothesis, which assumes that per capita real GDP has a unit-root, has not been rejected in any case. Accordingly, the CIPS test results reveal that the per capita real GDP for the fixed model has a unit-root. On the other hand, according to the BCIPS test results, the null hypothesis has been rejected in 5 out of 8 different situations, and evidence for the stationarity of per capita real GDP in G-7 countries has been found.

Table 4: The BCIPS and CIPS Panel Unit-root Tests for Per Capita Real GDP

\begin{tabular}{|l|c|c|c|c|}
\hline Constant and Trend Model & $(p, k)$ & {$[N, T]$} & CIPS & BCIPS \\
\hline $\mathrm{m}=1$ & $(1,2)$ & {$[7,50]$} & -2.5379 & $-3.4339^{* *}$ \\
\hline $\mathrm{m}=2$ & & & & \\
\hline
\end{tabular}


Tunahan HACIIMAMOĞLU, 2021 Cilt: 22, Sayl: 2, ss.123-144.

\begin{tabular}{|l|c|c|c|c|}
\hline Emp & $(1,2)$ & {$[7,50]$} & -2.4898 & -3.3993 \\
\hline Cap & $(2,1)$ & {$[7,50]$} & $-3.3116^{* * *}$ & -3.4164 \\
\hline Trade & $(2,1)$ & {$[7,50]$} & -2.8651 & $-3.6154^{* *}$ \\
\hline $\mathrm{m}=3$ & & & & \\
\hline Emp, Cap & $(4,2)$ & {$[7,50]$} & $-3.1859 * *$ & -2.7593 \\
\hline Emp, Trade & $(4,5)$ & {$[7,50]$} & $-3.3326 * * *$ & $-2.5104 * *$ \\
\hline Cap, Trade & $(3,3)$ & {$[7,50]$} & -2.8791 & $-3.2527^{* *}$ \\
\hline $\mathrm{m}=4$ & & & & \\
\hline Emp, Cap, Trade & $(2,5)$ & {$[7,50]$} & $-3.5328 * * *$ & $-3.6101 * * *$ \\
\hline
\end{tabular}

Note: $* * *$ and $* *$ represent $\% 1$ and $5 \%$ significance levels, respectively. $m$ indicates the number of factors in the model. The $p$ and $k$ are determined according to the Schwarz Bayesian Criterion (SBC) rule. Critical values are obtained from Pesaran (2007), Pesaran et al. (2013), Lee et al. (2016).

In Table 4, according to the CIPS test results, the null hypothesis, which states that per capita real GDP has a unit-root, has been rejected in 4 out of 8 different situations. In this regard, in the G-7 countries, the CIPS test results signify a presence of stationary in the per capita real GDP. According to the BCIPS test results, the null hypothesis has been rejected in 5 out of 8 different situations. Thereby, the evidence of stationary in per capita real GDP has amplified in G-7 countries. 


\section{IS PER CAPITA REAL GDP STATIONARY IN G-7 COUNTRIES? NEW EVIDENCE FROM A FOURIER PANEL UNIT ROOT TEST}

\section{CONCLUSION}

The concept of economic stability refers to a predictable and moderate fluctuation in macroeconomic variables. In this context, it is important for researchers and decision-makers to determine the stability of the main macroeconomic variables and whether the impacts of shocks on these variables are permanent. If the shocks are permanent, the impact of the shocks continues, that is, fluctuations in GDP cannot be stabilized in the long term. Additionally, if the shocks are temporary, the impact of shocks disappears, that is, fluctuations in GDP reach a longterm balance. On the other hand, if the effects of shocks are determined to be permanent, governments are expected to intervene in the economy with macroeconomic policy tools in order to balance the fluctuations. Otherwise, no monetary or fiscal policy is required to deal with shocks.

The aim of this study is to investigate the stationarity of per capita real GDP data in G-7 countries for the period of 1970-2019 with the BCIPS panel unit-root test proposed by Lee, Wu, and Yang (2016). From the results of the cross-section dependence tests, it has been determined that cross-section dependence exists in G-7 countries for per capita real GDP in the constant, and constant and trend models. According to the constant model, the BCIPS results have clarified that 5 out of 8 different cases follow a stationary process, while CIPS results have shown that the per capita real GDP data for all cases has a unit-root. According to the constant and trend model, while stationarity is detected for 4 out of 8 different cases in CIPS results, there is stationarity for 5 out of 8 different cases in BCIPS results. With the inclusion of common factors in the study, it is seen that more evidence on the existence of stationarity has been achieved. The findings from the BCIPS test have revealed that the per capita real GDP is stationary in G-7 countries. The findings are coherent with the view that business cycles exhibit stationary fluctuations around a deterministic trend. Furthermore, our results are consistent with the findings of the Narayan (2007) study. As a result, it has been determined that the impact of shocks at the output level is temporary in G-7 countries, that is, the fluctuations in GDP return to the long-term average. Employing monetary or fiscal policy instruments, it is not necessary to intervene in fluctuations occurring in the output level in G-7 countries. As a policy implication, it can be stated that a stabilization policy to be implemented in the G-7 countries may not have a permanent effect on the output level. Since stationary results have been detected for per capita real GDP in G-7 countries, co-integration relations involving other macro variables can not be investigated in this study. 
Tunahan HACIIMAMOĞLU, 2021 Cilt: 22, Sayl: 2, ss.123-144.

\section{REFERENCES}

Aslanidis, N., \& Fountas, S. (2014). Is Real GDP Stationary? Evidence from A Panel Unit Root Test with Cross-Sectional Dependence and Historical Data. Empirical Economics, 46(1), 101-108.

Azimi, D., \& Naim, M. (2015). A Unit Root Hypothesis: Is Afghanistan Real GDP Per Capita Stationary?(A Case Study for the Period 2001 to 2014). Journal of Economics and Business Research, 1(1).

Bai, J., \& Ng, S. (2004). A Panic Attack on Unit Roots and Cointegration. Econometrica, 72(4), 1127-1177.

Bai, J., \& Ng, S. (2010). Panel Unit Root Tests with Cross-Section Dependence: A Further Investigation. Econometric Theory, 1088-1114.

Banerjee, A. (1999). Panel Data Unit Roots and Cointegration: An Overview. Oxford Bulletin of Economics and Statistics, 61(S1), 607-629.

Becker, R., Enders, W., \& Lee, J. (2006). A Stationarity Test in the Presence of an Unknown Number of Smooth Breaks. Journal of Time Series Analysis, 27(3), 381-409.

Ben-David, D., \& Papell, D. H. (1995). The Great Wars, The Great Crash, and Steady State Growth: Some New Evidence About An Old Stylized Fact. Journal of Monetary Economics, 36(3), 453-475.

Breusch, T. S., \& Pagan, A. R. (1980). The Lagrange Multiplier Test and Its Applications to Model Specification in Econometrics. The Review of Economic Studies, 47(1), 239-253.

Campbell, J. Y., \& Mankiw, N. G. (1987). Are Output Fluctuations Transitory?. The Quarterly Journal of Economics, 102(4), 857-880.

Carrion-i-Silvestre, J., Del Barrio-Castro, T., \& López-Bazo, E. (2005). Breaking The Panels: An Application to the GDP Per Capita. The Econometrics Journal, 8(2), 159-175.

Cerrato, M., \& Sarantis, N. (2007). A Bootstrap Panel Unit Root Test Under Cross-Sectional Dependence, with An Application to PPP. Computational Statistics \& Data Analysis, 51(8), 4028-4037.

Chang, T., Chu, H. P., \& Ranjbar, O. (2014). Are GDP Fluctuations Transitory or Permanent in African Countries? Sequential Panel Selection Method. International Review of Economics \& Finance, 29, 380-399.

Chang, Y. (2002). Nonlinear IV Unit Root Tests in Panels with Cross-Sectional Dependency. Journal of Econometrics, 110(2), 261-292.

Chang, Y. (2004). Bootstrap Unit Root Tests in Panels with Cross-Sectional Dependency. Journal of Econometrics, 120(2), 263-293.

Chang, T. (2005). Is Per Capita Real GDP Stationary? Evidence from Selected African Countries Based on More Powerful Nonlinear (Logistic) Unit Root Tests. In Economics Bulletin. 


\section{IS PER CAPITA REAL GDP STATIONARY IN G-7 COUNTRIES? NEW EVIDENCE FROM A FOURIER PANEL UNIT ROOT TEST}

Chen, S. W. (2008). Are 19 Developed Countries' Real Per Capita GDP Levels Non-stationary? A Revisit. Economics Bulletin, 3(2), 1-11.

Cheung, Y. W., \& Chinn, M. D. (1996). Deterministic, Stochastic, and Segmented Trends in Aggregate Output: A Cross-Country Analysis. Oxford Economic Papers, 48(1), 134 162.

Cushman, D. O. (2016). A Unit Root in Postwar US Real GDP Still Cannot Be Rejected, and Yes, It Matters. Econ Journal Watch, 13(1), 5-45.

Çinar, S. (2010). OECD Ülkelerinde Kişi Başi GSYİH Durağan Mi? Panel Veri Analizi. Marmara Üniversitesi İktisadi ve İdari Bilimler Dergisi, 29(2), 591-601.

Enders, W., \& Lee, J. (2012). A Unit Root Test Using A Fourier Series to Approximate Smooth Breaks. Oxford Bulletin of Economics and Statistics, 74(4), 574-599.

Evans, G. W. (1989). A Measure of the US Output Gap. Economics Letters, 29(4), 285-289.

Firat, H. (2016). Is Real GDP Stationary? Evidence from Some Unit Root Tests for the Advanced Economies. Journal of Social and Economic Statistics, 5(2), 60-80.

Guloglu, B., \& İvrendi, M. (2010). Output Fluctuations: Transitory or Permanent? The Case of Latin America. Applied Economics Letters, 17(4), 381-386.

Im, K. S., Lee, J., \& Tieslau, M. (2005). Panel LM Unit-Root Tests With Level Shifts. Oxford Bulletin of Economics and Statistics, 67(3), 393-419.

Im, K. S., Pesaran, M. H., \& Shin, Y. (2003). Testing for Unit Roots in Heterogeneous Panels. Journal of Econometrics, 115(1), 53-74.

Kira, A. R. (2013). The Factors Affecting Gross Domestic Product (GDP) in Developing Countries: The Case of Tanzania. European Journal of Business and Management, 148158.

Konat, G., \& Kızılkaya, O. (2020). Seçilmiş OECD Ülkelerinde GSYİH Durağanlık Sınaması: Keskin ve Yumuşak Kırılmalı Panel Durağanlık Testi. Bitlis Eren Üniversitesi Iktisadi ve İdari Bilimler Fakültesi Akademik İzdüşüm Dergisi, 5(2), 216226.

Lee, K. C. (2014). Is Per Capita Real GDP Stationary in China? Sequential Panel Selection Method. Economic Modelling, 37, 507-517.

Lee, C., Wu, J. L., \& Yang, L. (2016). A Simple Panel Unit-Root Test with Smooth Breaks in the Presence of a Multifactor Error Structure. Oxford Bulletin of Economics and Statistics, 78(3), 365-393.

Levin, A., Lin, C. F., \& Chu, C. S. J. (2002). Unit Root Tests in Panel Data: Asymptotic and Finite- Sample Properties. Journal of Econometrics, 108(1), 1-24.

Lucas Jr, R. E. (1988). On the Mechanics of Economic Development. Journal of Monetary Economics, 22(1), 3-42. 
Maddala, G. S., \& Wu, S. (1999). A Comparative Study of Unit Root Tests with Panel Data and A New Simple Test. Oxford Bulletin of Economics and Statistics, 61(S1), 631-652.

Menyah, K., Nazlioglu, S., \& Wolde-Rufael, Y. (2014). Financial Development, Trade Openness and Economic Growth in African Countries: New Insights from A Panel Causality Approach. Economic Modelling, 37, 386-394.

Moon, H. R., \& Perron, B. (2004). Testing for a Unit Root in Panels with Dynamic Factors. Journal of Econometrics, 122(1), 81-126.

Murray, C. J., \& Nelson, C. R. (2000). The Uncertain Trend in US GDP. Journal of Monetary Economics, 46(1), 79-95.

Murthy, V. N., \& Anoruo, E. (2009). Are Per Capita Real GDP Series in African Countries Non-stationary or Non-linear? What does Empirical Evidence Reveal?. Economics Bulletin, 29(4), 2492-2504.

Narayan, P. K. (2007). Are G7 Per Capita Real GDP Levels Non-Stationary, 1870-2001?. Japan and the World Economy, 19(3), 374-379.

Nelson, C. R., \& Plosser, C. R. (1982). Trends and Random Walks in Macroeconmic Time Series: Some Evidence and Implications. Journal of Monetary Economics, 10(2), 139-162.

Omay, T. (2015). Fractional Frequency Flexible Fourier form to Approximate Smooth Breaks in Unit Root Testing. Economics Letters, 134, 123-126.

Omay, T., Gupta, R., \& Bonaccolto, G. (2017). The US Real GNP Is Trend-Stationary After All. Applied Economics Letters, 24(8), 510-514.

Ozturk, I., \& Kalyoncu, H. (2007). Is Per Capita Real GDP Stationary in the OECD Countries? Evidence from a Panel Unit Root Test.

Pagan, A. R., \& Wickens, M. R. (1989). A Survey of Some Recent Econometric Methods. The Economic Journal, 99(398), 962-1025.

Perron, P., \& Phillips, P. C. (1987). Does GNP Have A Unit Root?: A Re-Evaluation. Economics Letters, 23(2), 139-145.

Pesaran, M. H. (2004). General Diagnostic Tests for Cross-Sectional Dependence in Panels.

Pesaran, M. H. (2007). A Simple Panel Unit Root Test in the Presence of Cross-Section Dependence. Journal of Applied Econometrics, 22(2), 265-312.

Pesaran, M. H., Smith, L. V., \& Yamagata, T. (2013). Panel Unit Root Tests in the Presence of a Multifactor Error Structure. Journal of Econometrics, 175(2), 94-115.

Pesaran, M. H., Ullah, A., \& Yamagata, T. (2008). A Bias-Adjusted LM Test of Error CrossSection Independence. The Econometrics Journal, 11(1), 105-127.

Phillips, P. C., \& Sul, D. (2003). Dynamic Panel Estimation and Homogeneity Testing Under Cross Section Dependence. The Econometrics Journal, 6(1), 217-259. 


\section{IS PER CAPITA REAL GDP STATIONARY IN G-7 COUNTRIES? NEW EVIDENCE FROM A FOURIER PANEL UNIT ROOT TEST}

Rapach, D. E. (2002). Are Real GDP Levels Nonstationary? Evidence from Panel Data Tests. Southern Economic Journal, 473-495.

Rodrigues, P. M., \& Robert Taylor, A. M. (2012). The Flexible Fourier form and Local Generalised Least Squares De-Trended Unit Root Tests. Oxford Bulletin of Economics and Statistics, 74(5), 736-759.

Romer, P. M. (1989). Human Capital and Growth: Theory and Evidence. National Bureau of Economic Research Working Paper Series, 3173.

Rudebusch, G. (1993). The Uncertain Unit Root in Real GNP. American Economic Review, 83(1), 264-272

Sargan, J. D., \& Bhargava, A. (1983). Testing Residuals from Least Squares Regression for Being Generated by the Gaussian Random Walk. Econometrica: Journal of the Econometric Society, 153-174.

Smith, L. V., Leybourne, S., Kim, T. H., \& Newbold, P. (2004). More Powerful Panel Data Unit Root Tests with an Application to Mean Reversion in Real Exchange Rates. Journal of Applied Econometrics, 19(2), 147-170.

Smyth, R. (2003). Is There a Unit Root in Per Capita Real GDP? Panel Data Evidence from Chinese Provinces. Asian Profile, 31(4), 289-296.

Smyth, R., \& Inder, B. (2004). Is Chinese Provincial Real GDP Per Capita Nonstationary?: Evidence from Multiple Trend Break Unit Root Tests. China Economic Review, 15(1), 1 $-24$.

Solow, R. M. (1956). A Contribution to the Theory of Economic Growth. The Quarterly Journal of Economics, 70(1), 65-94.

Stock, J. H., \& Watson, M. W. (1986). Does GNP Have A Unit Root?. Economics Letters, 22(23), 147-151.

Strauss, J. (2000). Is There A Permanent Component in US Real GDP. Economics Letters, 66(2), 137-142.

Stulz, R. M., \& Wasserfallen, W. (1985, January). Macroeconomic Time-Series, Business Cycles and Macroeconomic Policies. In Carnegie-Rochester Conference Series on Public Policy, 22, 9-53. North-Holland.

Su, C. W., \& Chang, H. L. (2011). Is Per Capita Real GDP Stationary in Central and Eastern European Countries? Evidence from the Flexible Fourier Test. Eastern European Economics, 54-65.

Tiwari, A. K., Chaudhari, A., \& Suresh, K. G. (2012). Are Asian Per Capita GDP Stationary? Evidence from First and Second Generation Panel Unit Root Tests. Transition Studies Review, 19(1), 3-11. 
Tunahan HACIIMAMOĞLU, 2021 Cilt: 22, Sayl: 2, ss.123-144.

Tülümce, S. Y., \& Zeren, F. (2013). Is The Real Per Capita GDP Stationary in the European Union Member States? New Evidence From the Unit Root Test in Nonlinear Heterogeneous Panel. Social Sciences, 8(3), 106-115.

Wallis, K. F. (1989). Macroeconomic Forecasting: A Survey. The Economic Journal, 99(394), 28-61.

Zeren, F., \& İşlek, H. (2019). Is Per Capita Real GDP Stationary in the D-8 Countries? Evidence from a Panel Unit Root Test. 67-86.

Zhang, N. J., Lii, P., Huang, Y., \& Su, C. (2007). Is Per Capita Real GDP Stationary in Chinai H Evidence Based on A Panel SURADF Approach. Economics Bulletin, 3(31), 1-12. 


\section{IS PER CAPITA REAL GDP STATIONARY IN G-7 COUNTRIES? NEW EVIDENCE FROM A FOURIER PANEL UNIT ROOT TEST}

\section{EXTENDED ABSTRACT}

In the related literature, Nelson and Plosser (1982) pioneered in examining the stationarity of macroeconomic variables and argued that modeling the output level by considering a trend stationary or a difference stationary process has important implications for macroeconomic policies. Initiated by Nelson and Plosser (1982), interest in this process continued to increase with the studies of Stulz and Wasserfallen (1985), Stocks and Watson (1986), Campbell and Mankiw (1987), Phillips and Perron (1987), Evans (1989), Rudebusch (1993), with work by BenDavid and Papell (1995), Cheung and Chinn (1996), Murray and Nelson (2000), Rapach (2002), Smyth and Inder (2004), Narayan (2007), Chen (2008). In the following years, the investigation of the stationarity of macroeconomic variables took place among the remarkable topics for policy makers and academics. By using different econometric methods, the stationarity of other macroeconomic variables (exchange rate, unemployment, inflation, energy consumption, etc.), especially per capita real GDP, was tested and it was tried to reveal whether the effect of shocks was temporary or permanent. On the other hand, it was observed that the effect of shocks on macroeconomic variables differed according to the country group examined, the period in question and the second generation econometric analysis methods. The fact that the shocks in the output are permanent indicates that the deviations on the GDP do not reach the long-term average balance and that the deviations in the GDP reach the long-term average if they are temporary. However, if the effects of shocks are determined to be permanent, governments are expected to intervene in the market with macroeconomic policy tools in order to balance the fluctuations. Otherwise, there is no need to implement any monetary or fiscal policy to deal with shocks.

While there is accumulating evidence that the real GDP data were unit rooted in the first period studies, it is argued that this result was due to the low power of the traditional unit root analysis methods used (Chang et al., 2005: 1). It is stated that the results obtained by first generation unit root analyses such as ADF are not reliable, considering the non-linear character of macroeconomic variables especially in recent years and the potential cross-sectional dependency problem among countries. To overcome this problem, it is critical to use nonlinear second generation test methods that allow cross-section dependency (Lee, 2014: 508).

Solow (1956), in his study titled "A Contribution to Economic Growth Theories", dealing with the facts regarding the concept of economic growth, drew attention to the importance of labor and capital inputs in determining the level of economic growth under the assumption of constant returns to scale and no externalities under perfect competition conditions. Lucas (1988) and Romer (1989) emphasized that the increase in human capital, the opening up of countries to foreign countries, and their economic integration within the framework of endogenous growth theories would have a positive effect on economic growth. In the context of these theories, whether per capita real GDP, which is the main variable of the study, was stationary or not was tested by including common factor variables such as labor (Emp), capital (Cap), and openness (Trade) into the model. Eickmeier (2009) stated that the number of unobserved common factors varying between 2 and 6 would be sufficient in the analysis of macroeconomic variables. In their studies, Lee et al. (2016) and Zeren and İşlek (2019) determined the number of factors $\left(\mathrm{m}_{\max }\right)$ to be as 4 . In this context, in this study, stationarity analyses were performed over $m_{\max }=4$. Data on GDP and Trade variables were obtained from the World Bank's (WB) "World Development Indicators (WDI)" database, and data on Emp and Cap variables were obtained from the "Penn World Table-10 (PWT)" published by Feenstra, Inklaar and Timmer (2015). Gauss 20 package program was used in the analysis. 
Tunahan HACIIMAMOĞLU, 2021 Cilt: 22, Sayl: 2, ss. 123-144.

Whether the macroeconomic variables are stationary or not is important in terms of the effect of shocks and the effectiveness of the policies implemented. Thus, in this study, it is aimed to test the stagnation of the G-7 country group consisting of Germany, the United States of America (USA), France, England, Italy, Japan and Canada through the per capita real GDP data between 1970 and 2019. The G-7 is an international organization established in 1975 by the world's leading industrial countries to take an active role in world politics and to combat global and economic challenges. The policies to be implemented by these countries, which are in the position of global economic power, direct the world economy.

In the first stage of the study, it was checked whether there was a dependency between the cross-sections using the cross-section dependency tests. Then, in the study, stationarity analyses were performed using the BCIPS panel unit root test method developed by Lee, Wu, and Yang (2016). Lee et al. (2016) extended the multi-factor error structure model of Pesaran Smith and Yamagata (2013) by using the Fourier function in this test. Thus, the extended IPS (BCIPS) test with breaks that allows cross-sectional dependence, multi-factor error structure, and smooth transition of structural changes in deterministic components was developed. The BCIPS panel unit root test, which is a new unit root test, performs quite well when $\mathrm{T}>100$. In addition, it is stated that this test performs well unless $\mathrm{T}<50$.

Due to factors such as globalization, technological progress, financial liberalization and trade openness, interdependence between countries is increasing. Therefore, cross-sectional dependence between countries should be checked first in studies. In this context, in the first stage of the study, the existence of cross-sectional dependence in G-7 countries was examined by Breusch and Pagan (1980) LM, Pesaran (2004) CDlm, Pesaran (2004) CD and Pesaran et al. (2008) LMadj tests. According to the cross-sectional dependence test results, the null hypothesis that there is cross-section independence for the G-7 countries was rejected at the $1 \%$ significance level for the intercept model, and intercept and trended model. Thus, it was determined that there is a cross-section dependency in the G-7 countries. In this context, it was concluded from the findings obtained from the present study that other G-7 countries were also affected by the shocks seen in one of the G-7 countries.

In the intercept model CIPS test results, it was determined that the per capita real GDP data for all situations in G-7 countries are unit-rooted, and in the BCIPS test results, 5 of the 8 different situations follow a stationary process. However, while stationarity was detected for 4 of 8 different cases in the intercept and trend model CIPS test results, stationarity was observed for 5 of 8 different cases in the BCIPS test results. Accordingly, the BCIPS test results with its Fourier feature and multi-factor structure revealed that the per capita real GDP data in G-7 countries had a stationary structure. As a result, it was determined that the effect of shocks at the output level in G-7 countries was temporary, that is, the fluctuations in GDP returned to the longterm average. It was determined that the results obtained are compatible with neoclassical economic policies, so there is no need to intervene with monetary or fiscal policy instruments in the fluctuations in output level in G-7 countries.

The original aspects of the study and its contributions to the literature can be listed as follows. First, it is important to determine whether the impact of shocks in macroeconomic indicators is permanent or not, in terms of determining appropriate policies and their effectiveness. Therefore, determining whether the fluctuations in GDP data, as an important macroeconomic indicator, stabilize in the long term becomes determinant in the policies to be implemented by all countries, regardless of developed and developing countries. Secondly, a new 


\section{IS PER CAPITA REAL GDP STATIONARY IN G-7 COUNTRIES? NEW EVIDENCE FROM A FOURIER PANEL UNIT ROOT TEST}

second generation unit root test was used in the unit root analysis of per capita real GDP in G-7 countries. The first generation unit root tests ignore the cross section dependency, and the second generation unit root tests mostly do not take the structural changes into account. The BCIPS unit root test is more advantageous than the first and second generation unit root tests in that it considers the cross-section dependency, pays attention to multi-factor structure and allows a smooth transition process in structural changes thanks to the Fourier feature. It can be stated that the unit root analysis results obtained for the G-7 countries are stronger due to the advantages it offers, and more consistent policy recommendations can be made in this direction. 